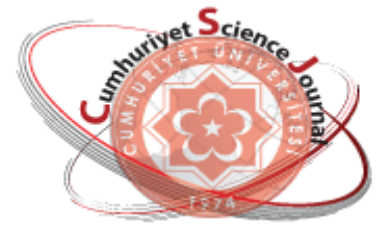

e-ISSN: $2587-246 X$

ISSN: $2587-2680$

\title{
Determination of Trace Levels of Nitrite in Beverages Samples Through Micellar Improved Catalytic Kinetic Spectrophotometry
}

\author{
Adil ELIKK ${ }^{l}$, Nail ALTUNAY ${ }^{1 *}$, Ramazan GÜRKAN ${ }^{l}$ \\ ${ }^{1}$ Department of Chemistry, Faculty of Science, Cumhuriyet University, TR-58140, Sivas, TURKEY
}

Received: 15.05.2017; Accepted: 05.06.2017

http://dx.doi.org/10.17776/csj.340413

\begin{abstract}
Abstrcat: In this study, a simple and sensitive catalytic kinetic spectrophotometry method for determination of nitrite has been described. The method is based on the oxidation of chlorpromazine by nitrite in presence of mixed surfactants in acidic medium, which results in the decrease in absorbance at $520 \mathrm{~nm}$. Various chemical (such as the effect of acidity, reagents concentrations) and instrumental parameters (time, sample volume and temperature) were optimized. The interfering effects of various chemical species were studied. At the optimum conditions, linear calibration graph was linear in the nitrite concentration ranges of $2.5-125 \mu \mathrm{g} \mathrm{L}^{-1}$. The detection limit is $0.71 \mu \mathrm{g} \mathrm{L}{ }^{-1}$ for nitrite. The relative standard deviation for determination of 25 and $75 \mu \mathrm{g} \mathrm{L}^{-1}$ were 3.40 and $2.35 \%$, for ten replicate measurements, respectively. The micellar improved catalytic kinetic spectrophotometry showed good analytical performance including good sensitivity, reproducibility, stability and selectivity to nitrite. The method has been applied to determine nitrite in beverages samples with a satisfactory recovery in the range of $97.3-103.8 \%$, showing its promising application for food safety monitoring.
\end{abstract}

Keywords: Chlorpromazine, Nitrite, Catalytic Kinetic, Surfactants, Spectrophotometry, Beverage Samples

\section{Misel İyileştirilmiş Katalitik Kinetik Spektrofotometri Aracılığıyla İçecek Örneklerinde Eser Düzeylerdeki Nitritin Belirlenmesi}

\begin{abstract}
Özet: $\mathrm{Bu}$ çalışmada nitrite tayini için basit ve hassas bir katalitik kinetik spektrofotometre yöntemi anlatılmıştır. Yöntemin temeli, asitli ortamda (520 nm'de emiliminde azalma olur) karışık yüzeyaktif maddeler varlığında nitrit ile klorpromazinin oksidasyonuna dayanır. Çeşitli kimyasal (asitlik etkisi, reaktif konsantrasyonları gibi) ve enstrümantal parametreler (zaman, numune hacmi ve sıcaklık) optimize edilmiştir. Çeşitli kimyasal türlerin girişim etkileri incelendi. Optimum koşullarda, doğrusal kalibrasyon grafiği, 2.5-125 $\mu \mathrm{g} \mathrm{L}{ }^{-1}$ nitrit derişimi aralıklarında doğrusal idi. Nitrit için tespit limiti $0.71 \mu \mathrm{g} \mathrm{L}^{-1}$ 'dir. Nitritin 25 ve $75 \mu \mathrm{g} \mathrm{L}^{-1}$ derişimleri için göreceli standart sapma değerleri sırasıyla \% 3.40 ve \% 2.35 dir. Misel geliştirilmiş katalitik kinetik spektrofotometri, iyi hassasiyet, tekrarlanabilirlik, kararlılık ve nitrite seçicilik de dahil olmak üzere iyi analitik performans göstermiştir. Yöntemin, içecek örneklerine uygulanması sonucu \% 97.3-103.8 aralığında tatmin edici geri kazanım değerleri elde edilmiştir. Sonuç olarak, önerilen yöntemin gıda güvenliği için umut verici bir uygulama olduğunu göstermektedir.
\end{abstract}

Anahtar Kelimeler: Klorpromazin, Nitrit, Katalitik Kinetik, Yüzey Aktif Maddeler, Spektrofotometri, İçecek Örnekleri

\section{INTRODUCTION}

Nitrite is a pollutant commonly found in food, natural water, and soils. It forms nitrosamines which are the resultant carcinogenic reaction with secondary amines in the acidic media. The US Public Health Authority has introduced $0.06 \mathrm{mg}$

\footnotetext{
* Corresponding author. Email address: naltunay@cumhuriyet.edu.tr

http://dergipark.gov.tr/csj C2016 Faculty of Science, Cumhuriyet University
} 
$\mathrm{L}^{-1}$ nitrite as drinking water [1]. In addition, the acceptable daily amount of nitrites given by the Joint FAO/WHO Food Additives Expert Committee (JECFA) and the Food Scientific Committee (SCF) is $0-0.07 \mathrm{mg} \mathrm{kg}^{-1}$ [2,3]. Because of all these reasons, there is still a need for simple, low-cost, fast, sensitive, selective and accurate analytical methods for determination of nitrite ions at trace levels.

There are various analytical methods for determination of nitrite in real samples. Some of the recent methods include spectrophotometry and spectrofluorimetry [4,5], polarography [6], FIA-chemiluminescence [7], high performance liquid chromatography (HPLC) with chemiluminescence detection [8], ion chromatography (IC) with spectrophotometric detection [9], capillary electrophoresis (CE) with contactless conductivity detection [10], and electrochemical biosensor [11]. However, chromatographic methods use expensive instruments and / or materials and high purity solvents. However, when combined with the preconcentration step, spectrophotometric methods may be used. It also provides high sensitivity is suitable chromogenic reagents are available. A large number of spectrophotometric methods involving the American Analytical Chemists Organization (AOAC) method are based on the diazotization of various aromatic amines with nitric acid on various conditions to form the diazonium salt [12]. The catalytic method is one of the most attractive procedures in terms of accuracy and does not require expensive or special equipment. These methods are based on the chemical reaction rate is influenced by the reaction conditions. [13]. These methods have advantages such as high sensitivity, extremely low detection limit, good selectivity, fast analysis rate and cheap instruments [14] The use of an activator in catalyzed reactions is usually designed to increase sensitivity and thus reduce the detection limit for the catalyst and increase the selectivity and sensitivity of the determination. Another way for this is the use of organic microheterogen system surface active agents [15]. Surfactant molecules and their aggregates above or around the critical micelle concentration (CMC) over the last two decades are increasingly being used by analytical techniques to change the time of analysis, including reactivity of analytes, as well as their sample rate and properties [16-18].

Many kinetic methods are based on the catalytic effect of nitrite on the decolorization of colored compounds such as pyrogallol red [19], brilliant cresyl blue [20], cresyl blue [21], methylene blue [22], bromocresol purple [23], pyrogallolsulfonephthalein [24], methylthymol blue [25], molybdosilicic acid blue [26] and acridine red [27].

The main objective of this research was to develop a simple, fast, and sensitive system for determination of nitrite by a kinetic spectrophotometric method based on its catalytic effect on the oxidation of Chlorpromazine by nitrite in presence of mixed surfactants in acidic medium. The mixed surfactants have low surface tension and strong solubilization power, so it can enhance the rate of reaction. High sensitivity and low detection limit can be achieved. Moreover, good reproducibility, technical simplicity and noticeable improvement in sensitivity and selectivity with utility of SDS and Triton X-114 around CMC for the determination of nitrite in beverage samples are the other advantages of the proposed method.

\section{MATERIALS AND METHODS}

\subsection{Reagents}

All the chemicals used were produced without further purification from the analytical reagent. A standard stock solution of $1000 \mathrm{mg} \mathrm{L}^{-1}$ sodium nitrite was prepared by dissolving appropriate amount of sodium nitrite (Sigma, Aldrich, USA) in deionized water. Working solutions of sodium nitrite were prepared from the stock solution by appropriate dilutions. A $3.0 \times 10^{-3} \mathrm{~mol} \mathrm{~L}^{-1}$ Chlorpromazine (CPZ) solution was prepared by dissolving appropriate amount of CPZ (Sigma) in mixed deionized water and ethanol $(4: 1, \mathrm{v} / \mathrm{v})$. The solutions of $5.0 \%(\mathrm{v} / \mathrm{v})$ of surfactants 
anionic sodium dodecyl sulfate (SDS) and nonionic, Triton X-114 (Sigma) were prepared by dissolving appropriate amount of surfactants in water in a volumetric flask of $100 \mathrm{~mL}$. The vessels and pipettes used for trace analysis were kept in $10 \%$ (w/v) $\mathrm{HNO}_{3}$ for at least $24 \mathrm{~h}$ and subsequently washed five times with the water.

\subsection{Apparatus}

A UV-Visible Spectrophotometer (Shimadzu UV-1800 PC, Kyoto, Japan), with a matching 1$\mathrm{cm}$ quartz cell was used for all spectrophotometric measurements at $520 \mathrm{~nm}$. pH values of the solutions were measured using a digital pH-meter, model pH-2005 (JP Selecta, Spain). A thermostatic water bath (EPC 4420, Termal, Istanbul, Turkey) was used to maintain the temperature in kinetic measurements. All solutions were preheated to an operating temperature of $40^{\circ} \mathrm{C}$ before the gauge reaction was initiated.

\subsection{Kinetic procedure}

Into a $15-\mathrm{mL}$ volumetric flask, a portion of the solution containing nitrite ion, nitrite in the concentration range of $2.5-125 \mu \mathrm{g} \mathrm{L}^{-1}$ was transferred into the volumetric flask and then 1.5 mol $\mathrm{L}^{-1}$ nitric acid and $0.075 \mathrm{mmol} \mathrm{L}^{-1}$ of Chlorpromazine were added. Then, $0.2 \%(\mathrm{v} / \mathrm{v})$ of Triton X-1114 and $10 \mathrm{mmol} \mathrm{L}^{-1}$ of SDS were added and solution was diluted with water to 15 $\mathrm{mL}$, mixed and left in $(40 \pm 0.5){ }^{\circ} \mathrm{C}$ bath water for fixed time of $3 \mathrm{~min}$. The absorbance of this catalyzed reaction, $\mathrm{A}_{\text {sample }}$ was labeled as nitrite and spectrophotometrically measured at $520 \mathrm{~nm}$. The same procedure was repeated without addition of analyte to get the blank signal (uncatalyzed reaction) and the signal was labeled as Ablank. The calibration graph was constructed by plotting $\Delta \mathrm{A}=\mathrm{A}_{\text {blank }}-\mathrm{A}_{\text {sample }}$ against nitrite concentration. The contents of nitrite in an unknown sample were determined using calibration graphs prepared at the same time.

\subsection{Analysis of Real Samples}

In the present study, all beverage samples were purchased from a supermarket in Sivas, Turkey.
Five milliliters of disodium tetraborate decahydrate $(0.2 \mathrm{M})$ was added to each sample. One hundred milliliters of hot water $\left(70-80{ }^{\circ} \mathrm{C}\right)$ was added to each sample. The samples were transferred to a bath for $10 \mathrm{~min}$. Two milliliters of potassium hexacyanoferrate $(0.25 \mathrm{M})$ and 2 $\mathrm{mL}$ of zinc acetate dihydrate $(1 \mathrm{M})$ to destruct the organic matrix were added to each sample. After $5 \mathrm{~min}$, the samples were filtered using a membrane filter $(0.45 \mathrm{~mm}$ pore size $)$ and centrifuged for $10 \mathrm{~min}$ at $4000 \mathrm{rpm}$. Five milliliters of each sample solution were used for real sample analysis [28]. Also, a blank extraction process was carried out through the same procedure. Then, the proposed method as described in section 2.3 was applied for determination of the nitrite in the selected samples.

\section{RESULTS AND DISCUSSION}

\subsection{Spectral characteristics}

The catalytic-kinetic system was monitored spectrophotometrically by measuring the decrease in absorbance against water at $520 \mathrm{~nm}$ for the fixed time of first $3 \mathrm{~min}$ from the initiation of the reaction. The absorption spectra of Chlorpromazine (CPZ) in the aqueous solution are shown in Figs. 1. Analytical results suggest that the absorbance values of the different systems reach peak at $520 \mathrm{~nm}$ and the oxidation of CPZ progresses in the presence of SDS and Triton X-114 with nitric acid medium. The reaction is accelerated with a small amount of nitrite followed by the measurement of absorbance at $525 \mathrm{~nm}$ : the nitrite ion is regenerated and multiplied with nitric acid. The absorbance of the reaction increased with increasing reaction time, reached maximal and decreased rapidly. Since the time required to reach the maximum absorption value decreases with increasing nitrite concentration, this value is used as the parameter to be measured for the nitrite determination. Therefore, kinetic determination should be carried out at $520 \mathrm{~nm}$. 


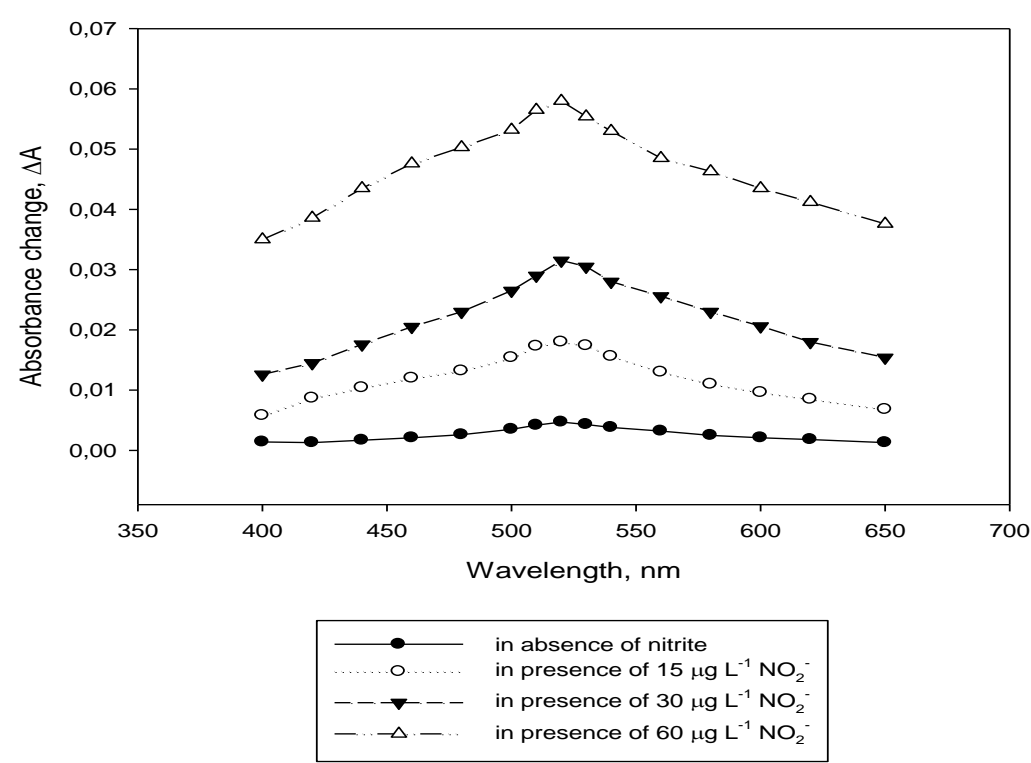

Figure 1. Absorbance change of micellar catalyzed indicator system with increasing nitrite concentration as a function of wavelength in presence of 15,30 and $60 \mu \mathrm{g} \mathrm{\textrm {L } ^ { - 1 }} \mathrm{NO}_{2}^{-}$.

\subsection{Optimization of Experimental Conditions}

\section{Effect of Acidity}

The effect of acidity on the reaction was investigated in range of $0.5-4.0 \mathrm{~mol} \mathrm{~L}-1$ nitric acid, and the results are shown in Figs. 2. It has been observed that the absorption of $\mathrm{CPZ}$ decreases gradually with increasing nitric acid concentration. Oxidation of nitrite and CPZ did not occur in the absence of nitric acid; however, in a small amount, the acid reaction was very rapid. There was an increase in $\Delta \mathrm{A}$ when the nitric acid concentration changed to $1.5 \mathrm{~mol} \mathrm{~L}^{-1}$, a decrease in the observed response at higher acid concentrations. For this reason, $1.5 \mathrm{~mol} \mathrm{~L}^{-1}$ nitric acid was added for subsequent measurements.

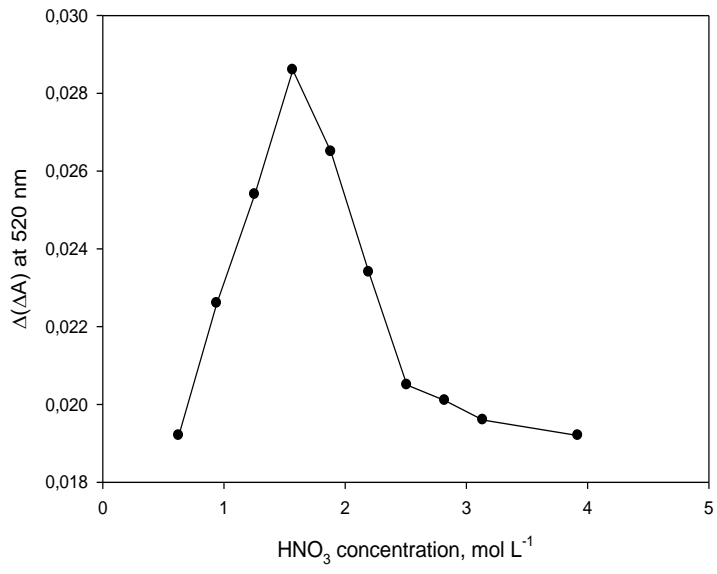

Figure 2. Effect of $\mathrm{HNO}_{3}$ concentrations on the analytical signal.

\section{Effect of CPZ Concentration}

Chlorpromazine

(3-(2-chloro-10Hphenothiazin-10-yl) -N, N-dimethylpropan-1amine, CPZ) is a well known antipsychotic phenothiazine derivative. In the presence of oxidizing agents $\mathrm{CPZ}$ is oxidized to a colorless sulphoxide derivative (CPZSO) that can be converted to a red radical cation (CPZ) by irreversible oxidation in the presence of an excess of oxidant. The oxidized form $\mathrm{CPZ}$ shows a strong absorption maximum at 520 (or $528 \mathrm{~nm}$ ), while PPZSO shows maximum 
absorption at $344 \mathrm{~nm}$. Thus, CPZ was used in the kinetic determinations of trace nitrite based on its catalytic effect on the redox reactions between $\mathrm{CPZ}$ and $\mathrm{HNO}_{3}, \mathrm{CPZ}$ and $\mathrm{H}_{2} \mathrm{O}_{2}$ in presence of oxalic acid in acidic media at 40 ${ }^{\circ} \mathrm{C}$ and $20{ }^{\circ} \mathrm{C}$, respectively [29,30]. The effect of $\mathrm{CPZ}$ concentration on the reaction was investigated in range of $0.0-0.3 \mathrm{mmol} \mathrm{L}^{-1}$ in presence of nitrite. As shown in Figure 3, the sensitivity (net reaction rate) increases with increasing CPZ concentration up to 0.075 mmol $\mathrm{L}^{-1}$ and decreases at higher concentrations. This decrease may be due to the aggregation of the dye at higher concentrations and acidic medium. Therefore, a final concentration of $0.075 \mathrm{mmol} \mathrm{L}^{-1}$ of $\mathrm{CPZ}$ was selected as the optimum concentration.

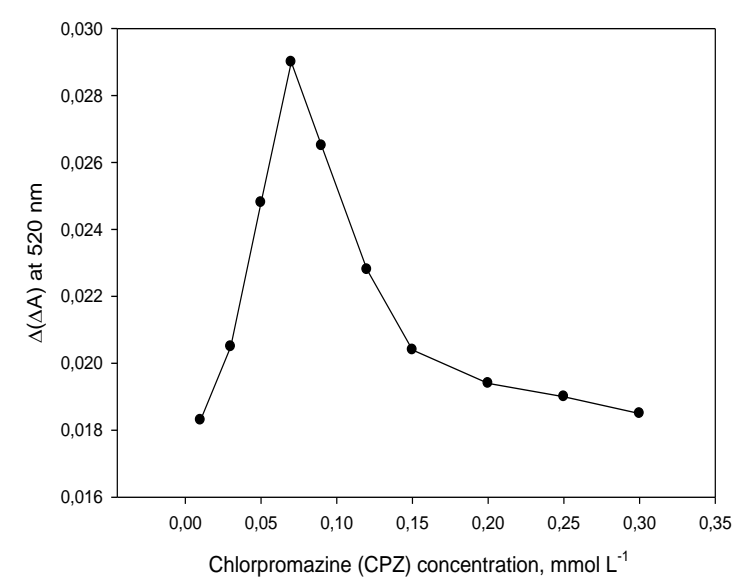

Figure 3. Effect of Chlorpromazine (CPZ) concentrations on the analytical signal.

\section{Effect of Surfactants Concentration}

In most cases, the speed and route of any chemical reaction can be changed by reacting in a micelle environment instead of pure bulk solvents [31,32]. These kinetic effects are generally explained by the partition between the aqueous and micellar phases of the substrate. Surfactants affect reaction rates by including micellar aggregates in one or both of the reagents. To select a suitable micelle system for the reaction, the load type on the reagents must account for the electrostatic and hydrophobic interactions between the micellar accelerating effect reagents and the micellar surface [33]. The SDS and Triton X-114 are anionic and non-ionic surfactants, respectively. CPZ is a positively charged cationic phenothiazine group dyespecie. Therefore, it is logical to consider that the anionic micelles can hydrophobically enhance the rate of the indicator reaction. The enhancement effect of anionic surfactant, SDS was observed on nitrite-catalyzed reaction by the electrostatic interaction of the species involved in the reaction with the negatively charged micellar surface. Also, it is clear that Triton X-114 having polar etoxy group synergistically leads to a significant inrease in reaction rate with hydrophobic and ion-dipol interactions. Due to the electrostatic attraction between the negatively charged micellar surface and positively charged CPZ involved in the reaction are effectively united and hence enhanced the collision frequency and in the result oxidation process became faster.

The effect of SDS concentration on the reaction rate was investigated in the concentration range of $0.0-25 \mathrm{mmol} \mathrm{L}^{-1}$. The results are shown in Figure 4. The absorbance has sharply increased with increasing SDS concentration up to $10 \mathrm{mmol} \mathrm{L}^{-1}$ and gradually decreased at higher concentrations, in which its critical micelle concentration is $8.2 \mathrm{mmol} \mathrm{L}^{-1}$. This increase in signal at $10 \mathrm{mmol} \mathrm{L}^{-1}$ can be due to monomer-dimer equilibrium occurring above CMC, so as to cause an increase in sensitivity and selectivity of indicator reaction. Therefore, a SDS concentration of $10 \mathrm{mmol} \mathrm{L}^{-1}$ was selected as the optimum concentration.

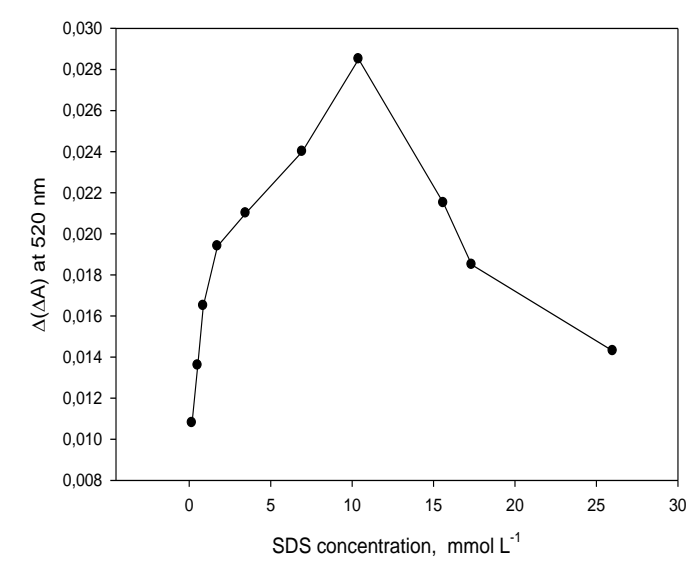

Figure 4. Effect of SDS concentration on the analytical signal. 
In order to stabilize the colored ternary complex formed and to increase the sensitivity, the effect of Triton X-114 concentration on the determination of nitrite was investigated in the concentration range of $0.0-1.0 \%(\mathrm{v} / \mathrm{v})$ The results (Figure 5) showed that Triton X-114 must be present in analytical system in a minimum concentration of $0.1 \%(\mathrm{v} / \mathrm{v})$ in order to avoid precipitation and turbidity. When this surfactant is present in the concentration range of $0.1-0.2 \%(\mathrm{v} / \mathrm{v})$, a pronounced increase in the absorbance signal was observed in presence of Triton X-114 except for stability of the metal-complex. Thus, a Triton X-114 concentration of $0.2 \%(\mathrm{v} / \mathrm{v})$ was selected as the optimum concentration.

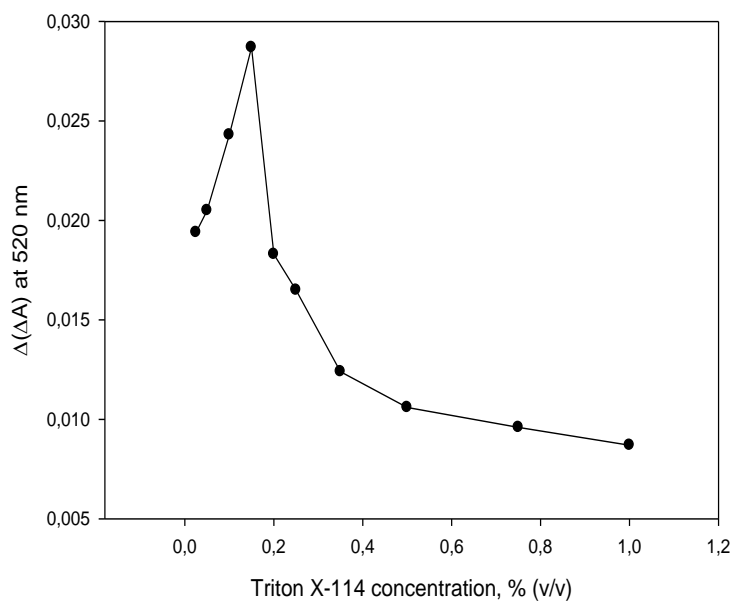

Figure 5. Effect of Triton X-114 concentration on the analytical signal.

\section{Effect of Reaction Temperature and Time}

In order to make a micelle-sensitized spectrophotometric measurement in a fast and easy way and to fullfill the complex formation reaction, the equilibrium temperature and time must be optimized. The effect of temperature on the catalyzed reaction of nitrite between nitrate and CPZ in presence of SDS and Triton $\mathrm{X}-114$ was investigated in range of $25-60{ }^{\circ} \mathrm{C}$. It can be seen from Fig. 6 that, as the temperature increases up to $40{ }^{\circ} \mathrm{C}$, the net reaction rate increases and gradually decreases at higher temperatures than $40{ }^{\circ} \mathrm{C}$. This means that the rate of uncatalyzed reaction increases with temperature in the range of $40-60{ }^{\circ} \mathrm{C}$ and increases as a result of increased signal void for the reduction of net signal difference. For this reason, a temperature of $40^{\circ} \mathrm{C}$ was chosen for studies.

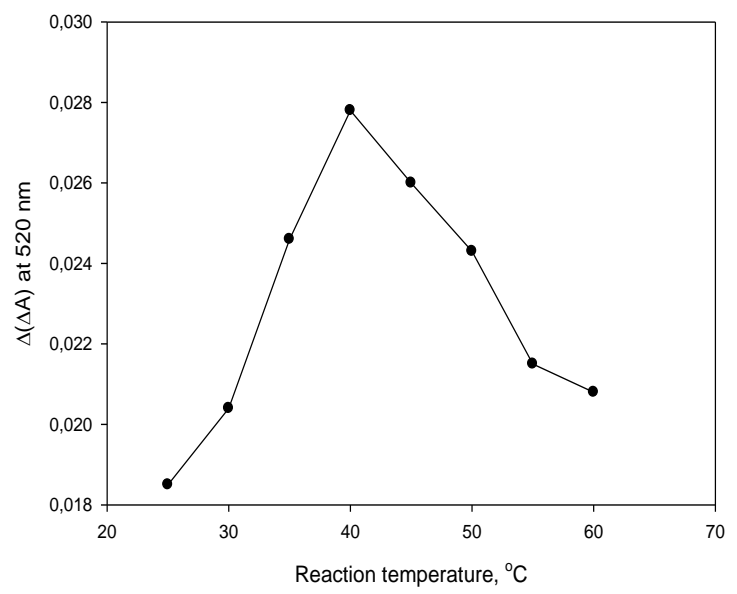

Figure 6. Effect of the catalyzed reaction temperature on the analytical signal.

Also, the dependency of absorbance on equilibrium time of reaction with and without catalyst was studied in the time range of 1-6 min and it was shown (Figure 7) that the signal difference between the reaction rates with and without catalyst is complete in approximately 3 min and the analytical signal reaches to maximum and almost keeps constant in range of 3-6 min, in terms of good reproducibility and stability of absorbance. An equilibrium time or kinetically fixed time of 3 min was chosen as an optimum value for catalytic measurements of nitrite present in sample matrices.

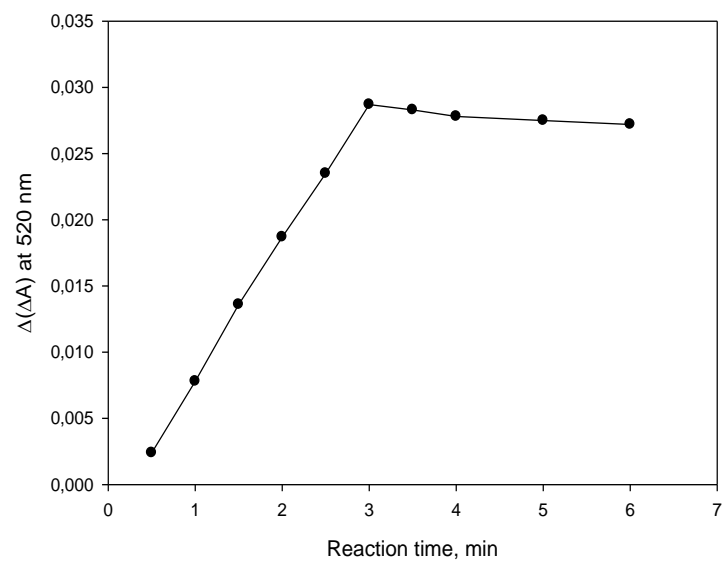

Figure 7. Effect of the catalyzed times on the analytical signal. 


\subsection{Analytical Performance}

Calibration curve was obtained using kinetically the fixed-time method of $3 \mathrm{~min}$, considering the signal differences between sample and analyte blanks. The kinetic method was directly applied to the change in absorbance over a time interval of 3-min from initiation of the reaction because it provided the best regression and calibration sensitivity. The analytical performance of the proposed procedure is summarized in Table 1. Under the optimal conditions, the difference in absorbance between blank and sample varied linearly with the concentration of nitrite in the range of $2.5-125 \mu \mathrm{g} \mathrm{L}^{-1}$ and fitted to the regression equation: $\Delta \mathrm{A}=8.86 \times 10^{-}$ ${ }^{4} \mathrm{C}+4.65 \times 10^{-3}$ with a correlation coefficient of 0.9963 , where $\mathrm{C}$ is the nitrite concentration expressed in $\mu \mathrm{g} \mathrm{L}^{-1}$. The detection limit calculated from three times the standard deviation of the blank divided by the slope of the calibration graph was $0.71 \mu \mathrm{g} \mathrm{L}^{-1}$. The relative standard deviation (RSD) as a measure of precision for ten replicate measurements of 25 and $75 \mu \mathrm{g} \mathrm{L}^{-1}$ of the nitrite were 3.40 and $2.35 \%$, respectively.

Table 1. Analytical capability and performance of the proposed method.

\begin{tabular}{cc}
\hline Analytical features & With Chlorpromazine at 520 nm \\
\hline Calibration equation & $\Delta \mathrm{A}=8.86 \times 10^{-4} \mathrm{C}+4.65 \times 10^{-3}$ \\
Correlation coefficient, $\mathrm{r}$ & 0.9963 \\
Linearity range, $\mu \mathrm{g} \mathrm{L}-1$ & $2.5-125$ \\
Detection limit, $\mu \mathrm{g} \mathrm{L}^{-1}$ & 0.71 \\
Quantification limit, $\mu \mathrm{g} \mathrm{L}^{-1}$ & 2.37 \\
Precision as RSD $\%\left(\mathrm{n}: 5,5,25\right.$ and $\left.75 \mu \mathrm{g} \mathrm{L}^{-1}\right)$ & $2.35-5.15$ \\
Recoveries \% $\left(5,25\right.$ and $\left.75 \mu \mathrm{g} \mathrm{L}^{-1}, \mathrm{n}: 5\right)$ & $97.5-103.2$ \\
\hline
\end{tabular}

\subsection{Selectivity Study}

In order to establish the applicability of the method to beverage samples, the selectivity of the method was evaluated by determining 50 $\mu \mathrm{g} \mathrm{L^{-1 }}$ of nitrite in the presence of varying amounts of cations and anions which are potentially present in beverage samples. The tolerance limit was identified as the concentration of added ion that caused more than $\pm 5.0 \%$ relative error in the absorbance of the sample aganst analyte blank for fixed time of $3 \mathrm{~min}$. As understood from the results in Table 2, large excess amounts of interferents had no obvious effect on the determination of the nitrite under the optimum conditions. According to the results, except $\mathrm{Fe}^{3+}$ and $\mathrm{Cu}^{2+}$, no ion interferes at the same level of thiourea, so the method has relatively good selectivity. When the concentrations of $\mathrm{Fe}^{3+}$ and $\mathrm{Cu}^{2+}$ ions are present at hihgher levels than tolerance limits in real samples respectively, $\mathrm{NaF}$ and thiourea at suitable eamounts as masking agents can be used to reduce possible interference effects for each species. Also, the effect of other interference cationic ions including $\mathrm{Fe}^{3+}$ and $\mathrm{Cu}^{2+}$ can be greatly diminished by addition of $0.1 \%$ EDTA $(0.25 \mathrm{~mL})$ solution. 
Table 2. Tolerance ratio for the determination of $50 \mu \mathrm{g} \mathrm{L}^{-1}$ of nitrite.

\begin{tabular}{lccc}
\hline Species & $\begin{array}{c}\text { Tolerance limit } \\
\text { [ Interfering species/ the nitrite] }\end{array}$ & Species & $\begin{array}{c}\text { Tolerance limit } \\
\text { [ Interfering species/ the nitrite] }\end{array}$ \\
\hline $\mathrm{Zn}^{2+}$ & 1000 & oksalat & 300 \\
$\mathrm{Ba}^{2+}$ & 1000 & $\mathrm{sitrat}^{2+}$ & 250 \\
$\mathrm{Mn}^{2+}$ & 1000 & $\mathrm{SO}_{4}{ }^{2-}$ & 250 \\
$\mathrm{Br}^{-}$ & 750 & $\mathrm{Ni}^{2+}$ & 200 \\
$\mathrm{CO}_{3}{ }^{2-}$ & 750 & $\mathrm{NO}_{3}{ }^{-}$ & 175 \\
$\mathrm{Ag}^{+}$ & 500 & $\mathrm{PO}_{4}{ }^{3-}$ & 100 \\
$\mathrm{CN}^{-}$ & 500 & $\mathrm{Mn}^{2+}$ & 75 \\
$\mathrm{Mn}^{2+}$ & 500 & $\mathrm{Fe}^{3+}$ & 50 \\
$\mathrm{Cr}^{3+}$ & 400 & $\mathrm{Cu}^{2+}$ & 25 \\
\hline
\end{tabular}

\subsection{Accuracy of the Method}

In order to verify the accuracy of the proposed method, the method was applied to the determination of total nitrite of the certified reference material (CRM). Suitable aliquots of the CRM such as CRM Seawater, MOOS-1 with copper contents of $141 \pm 7 \mu \mathrm{g} \mathrm{L}^{-1}$ was diluted to a final volume of $50 \mathrm{~mL}$ with water and other reagents used in preconcentration step prior to analysis by spectrophotmetry. The analytical results were summarized in Table 3. From the analysis results, using the current kinetic method, it has been observed that the results obtained from five replicate measurements of samples by means of the proposed method are statistically in good agreement with the certified values. It can be concluded that the method is accurate and free from systematic errors. Also, in order to control the accuracy and precision of the proposed method, recovery studies from spiked samples was performed in five replicate measurements at a concentration level $(10,15$ $\mu \mathrm{g} \mathrm{L}^{-1}$ ) of nitrite for beverage samples by using comparatively direct calibration and standard addition calibration curves. The experimental $\mathrm{t}$ - and F-values obtained from analysis results are also smaller than the tabulated $\mathrm{t}$ - and F-values, so it may be concluded that the values obtained are significantly equal to the certified values.

\subsection{Applications}

We were successfully investigated the feasibility of the proposed method by determining the nitrite in beverage samples. The samples were pretreated according to the procedure described in Section 2.4. Three milliliters of the prepared solution samples were transferred separately to a $50 \mathrm{~mL}$ volumetric tube. Subsequently, the method at the range of 2.5-125 $\mu \mathrm{g} \mathrm{L}^{-1}$ nitrite was applied to determine the nitrite levels using standard post-treatment addition and direct calibration curves. The results and recovery of the samples added at concentrations between 10 and $15 \mu \mathrm{g}$ $\mathrm{L}^{-1}$ after dilution are given in Table 3. In all cases, calibration was performed using aqueous standard calibration curves. It is observed that the recovery of gravel solutions varies quantitatively from $97 \%$ to $99.3 \%$ for the samples. The precision of the five-replicate assay is generally better than the maximum $5.33 \%$ RSD for nitrite. The results show that the proposed method is a sensitive and selective method in which trace amounts of nitrite in beverage samples are determined with satisfactory results. 
Tablo 3. The dissolved nitrite levels of nonalcoholic and alcoholic beverage samples and the recovery results of spiked samples.

\begin{tabular}{|c|c|c|c|c|c|c|c|c|c|c|c|}
\hline \multirow{3}{*}{ Samples } & \multirow{3}{*}{$\begin{array}{c}\text { Sample } \\
\text { volume, } \\
\text { mL }\end{array}$} & \multicolumn{8}{|c|}{$\begin{array}{l}\text { In presence of } 1.5 \mathrm{~mL} \text { of } 0.01 \mathrm{~mol} \mathrm{~L}^{-1} \text { EDTA after preteratment, fitration and dilution with } \\
\qquad 1.5 \mathrm{~mL} \mathrm{of} 3.0 \%(\mathrm{v} / \mathrm{v}) \mathrm{CH}_{3} \mathrm{COOH} \text { at } 65^{\circ} \mathrm{C}\end{array}$} & \multirow{3}{*}{$\begin{array}{c}\text { Certified } \\
\text { value, } \mu \mathrm{g} \mathrm{L^{-1 }} \\
(\mathrm{N}: 5)\end{array}$} & \multirow{3}{*}{$\begin{array}{c}\text { Calculated } \\
\text { statistical t- and } \\
\text { F-values }\end{array}$} \\
\hline & & \multicolumn{4}{|c|}{ With direct calibration curve, $(\mathrm{N}: 5)$} & \multicolumn{4}{|c|}{ With standard addition calibration curve, (N: 5) } & & \\
\hline & & $\begin{array}{l}\text { Added, } \\
\mu \mathrm{g} \mathrm{L}^{-1}\end{array}$ & $\begin{array}{l}\text { Found, } \\
\mu \mathrm{g} \mathrm{L}^{-1}\end{array}$ & $\begin{array}{c}\text { RSD } \\
\%\end{array}$ & $\begin{array}{l}\text { Recovery } \\
\%\end{array}$ & $\begin{array}{l}\text { Added, } \\
\mu \mathrm{g} \mathrm{L^{-1 }}\end{array}$ & $\begin{array}{l}\text { Found, } \\
\mu \mathrm{g} \mathrm{L^{-1 }}\end{array}$ & $\begin{array}{c}\text { RSD } \\
\%\end{array}$ & $\begin{array}{l}\text { Recovery } \\
\%\end{array}$ & & \\
\hline \multirow{2}{*}{ Fizzy Drink 1} & \multirow{2}{*}{3} & - & $42.60 \pm 1.40$ & 3.29 & - & - & $41.30 \pm 1.35$ & 3.27 & - & - & $1.50,0.93$ \\
\hline & & 10 & $52.35 \pm 1.42$ & 2.71 & 97.5 & 10 & $51.20 \pm 1.40$ & 2.74 & 99.0 & - & - \\
\hline \multirow{2}{*}{ Fizzy Drink 2} & \multirow{2}{*}{3} & - & $38.10 \pm 1.35$ & 3.54 & - & - & $36.70 \pm 1.28$ & 3.49 & - & - & $1.29,0.97$ \\
\hline & & 10 & $47.80 \pm 1.45$ & 3.03 & 97.0 & 10 & $46.50 \pm 1.42$ & 3.05 & 98.0 & - & - \\
\hline \multirow{2}{*}{ Orange juice } & \multirow{2}{*}{3} & - & $35.80 \pm 1.30$ & 3.63 & - & - & $34.50 \pm 1.25$ & 3.62 & - & - & $1.61,1.02$ \\
\hline & & 10 & $45.70 \pm 1.42$ & 3.11 & 99.0 & 10 & $44.30 \pm 1.35$ & 3.05 & 98.0 & - & - \\
\hline \multirow{2}{*}{ Cherry juice } & \multirow{2}{*}{3} & - & $15.10 \pm 0.80$ & 5.30 & - & - & $14.30 \pm 0.70$ & 4.90 & - & - & $1.68,1.31$ \\
\hline & & 10 & $24.80 \pm 1.0$ & 4.03 & 97.0 & 10 & $24.10 \pm 0.85$ & 3.53 & 98.0 & - & - \\
\hline \multirow{2}{*}{ Mixed fruit juice } & \multirow{2}{*}{3} & - & $53.50 \pm 1.60$ & 2.99 & - & - & $51.60 \pm 1.50$ & 2.91 & - & - & $1.94,1.14$ \\
\hline & & 10 & $63.30 \pm 1.75$ & 2.76 & 98.0 & 10 & $61.45 \pm 1.70$ & 2.77 & 98.5 & - & - \\
\hline \multirow{2}{*}{ Pomegranate juice } & \multirow{2}{*}{3} & - & $57.90 \pm 1.70$ & 2.94 & - & - & $55.80 \pm 1.60$ & 2.87 & - & - & $2.01,1.13$ \\
\hline & & 10 & $67.50 \pm 1.85$ & 2.74 & 96.0 & 10 & $65.55 \pm 1.75$ & 2.67 & 97.5 & - & - \\
\hline \multirow[t]{2}{*}{ Grapes juice } & 3 & - & $35.00 \pm 1.30$ & 3.71 & - & - & $33.60 \pm 1.20$ & 3.57 & - & - & $1.77,1.17$ \\
\hline & & 15 & $49.80 \pm 1.42$ & 2.85 & 98.7 & 15 & $48.20 \pm 1.35$ & 2.80 & 97.3 & - & - \\
\hline \multirow{2}{*}{ Apple vinegar } & 3 & - & $34.10 \pm 1.30$ & 3.81 & - & - & $32.80 \pm 1.23$ & 3.75 & - & - & $1.27,1.06$ \\
\hline & & 15 & $43.80 \pm 1.40$ & 3.20 & 97.0 & 15 & $47.70 \pm 1.35$ & 2.83 & 99.3 & - & - \\
\hline \multirow[t]{2}{*}{ Red wine } & 3 & - & $33.60 \pm 1.30$ & 3.87 & - & - & $32.80 \pm 1.25$ & 3.85 & - & - & $0.99,1.08$ \\
\hline & & 15 & $48.45 \pm 1.40$ & 2.89 & 99.0 & 15 & $47.50 \pm 1.35$ & 2.84 & 98.0 & - & - \\
\hline \multirow[t]{2}{*}{ Beer } & 3 & - & $28.60 \pm 1.10$ & 3.85 & - & - & $27.20 \pm 1.0$ & 3.68 & - & - & $2.11,1.21$ \\
\hline & & 15 & $43.40 \pm 1.30$ & 3.00 & 98.7 & 15 & $41.90 \pm 1.20$ & 2.86 & 98.0 & - & - \\
\hline $\begin{array}{l}{ }^{a} \text { CRM Seawater, } \\
\text { MOOS-1 }\end{array}$ & 10 & & $138.6 \pm 6.3$ & 4.55 & 98.3 & - & $142.30 \pm 5.8$ & 4.08 & 100.9 & $141 \pm 7$ & $\begin{array}{c}0.852,0.501 \\
1.23,1.46\end{array}$ \\
\hline
\end{tabular}

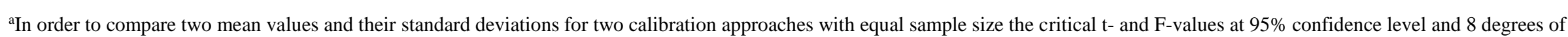
freedom are 2.31 and 6.39 , respectively.

${ }^{b}$ In order to compare the certified value and the measured values obtained by using two calibration approaches the critical t- and F-values at $95 \%$ confidence level and 4 degrees of freedom are 2.31 and 6.39 , respectively 


\section{CONCLUSIONS}

In this paper, a simple, relatively rapid, low cost, highly sensitive, and selective method due to micellar protection is proposed for the determination of trace levels of nitrite based on its catalytic effect on the oxidation of $\mathrm{CPZ}$ as the chromogenic reagent in nitric acid media and presence of SDS and Triton X-114. The method does not require any separation or preconcentration steps, and can be directly applied to the determination of nitrite in beverage samples. Analytical characteristics of the method, such as sensitivity and selectivity, limits of detection and quantification and linear working range were determined for nitrite. The interference analysis showed that almost no foreign ions interfere with the determination. The main advantage of the method relates to fast, precise, selective and short analysis time.

\section{Acknowledgments}

Financial assistance from the Cumhuriyet University Scientific Research Projects Commission (CUBAP), Sivas in Turkey, is sincerely thanked.

\section{REFERENCES}

[1]. Z.T. Jiang, Y.X. Guo, and R. Li, "Spectrophotometric determination of trace nitrite with brilliant cresyl blue using $\beta$-cyclodextrin as a sensitizer," Food Analytical Methods, 3(1), 47-53 (2010).

[2]. P.K. Rastogi, V. Ganesan, and S. Krishnamoorthi, "A promising electrochemical sensing platform based on a silver nanoparticles decorated copolymer for sensitive nitrite determination,' Journal of Materials Chemistry A, 2(4), 933-943 (2014).

[3]. P. Erkekoglu, H. Sipahi, T. Baydar, Evaluation of nitrite in ready-made soups," Food Anal Methods 2:61-65 (2009).

[4]. N. Altunay, R. Gürkan, and E. Olgaç, "Development of a New Methodology for Indirect Determination of Nitrite, Nitrate, and Total Nitrite in the Selected
Two Groups of Foods by Spectrophotometry," Food Analytical Methods, 1-13 (2017).

[5]. Q. Wang, S. Ma, H. Huang, A. Cao, M. $\mathrm{Li}$, and $\mathrm{L}$. He, "Highly sensitive and selective spectrofluorimetric determination of nitrite in food products with a novel fluorogenic probe," Food Control, 63, 117-121 (2016).

[6]. G. Somer, Ş. Kalaycı, and Z. Almas, "A new, fast and sensitive method for the determination of trace amounts of nitrite using differential pulse polarography," Nitric Oxide, 57, 79-84 (2016).

[7]. P. Mikuška, and Z. Večeřa, "Simultaneous determination of nitrite and nitrate in water by chemiluminescent flow-injection analysis," Analytica chimica acta, 495(1), 225-232 (2003).

[8]. H. Kodamatani, S. Yamazaki, K. Saito, T. Tomiyasu, and Y. Komatsu, "Selective determination method for measurement of nitrite and nitrate in water samples using high-performance liquid chromatography with post-column photochemical reaction and chemiluminescence detection," Journal of Chromatography A, 1216(15), 31633167 (2009).

[9]. Z. Binghui, Z. Zhixiong, and Y. Jing, "Ion chromatographic determination of trace iodate, chlorite, chlorate, bromide, bromate and nitrite in drinking water using suppressed conductivity detection and visible detection," Journal of Chromatography A, 1118(1), 106-110 (2006).

[10]. P. Kubáň, H.T.A. Nguyen, M. Macka, P.R. Haddad, and P.C. Hauser, "New fully portable instrument for the versatile determination of cations and anions by capillary electrophoresis with contactless conductivity detection," Electroanalysis, 19(19-20), 2059-2065 (2007).

[11]. M. Eguilaz, L. Agüí, P. Yanez-Sedeno, and J.M. Pingarron, "A biosensor based on cytochrome c immobilization on a poly-3-methylthiophene/multi-walled carbon nanotubes hybrid-modified 
electrode. Application to the electrochemical determination of nitrite,' Journal of Electroanalytical Chemistry, 644(1), 30-35 (2010).

[12]. AOAC AOAC Method 36121. In: Cunniff $\mathrm{P}$ (ed) Official Methods of Analysis, 16th edn. AOAC, Gaithersburg, pp 8-9, (1995)

[13]. Aydin, Ö. Ercan, and S. Tascioğlu, "A novel method for the spectrophotometric determination of nitrite in water," Talanta, 66, 181-1186 (2005).

[14]. R. Gürkan, T. Çepken, and H.I. Ulusoy, "Surfactant-sensitized spectrophotometric determination of $\mathrm{Hg}$ (II) in water samples using 2-(2thiazolylazo)-p-cresol as ligand and cetylpyridinium chloride as cationic surfactant," Turkish Journal of Chemistry, 36(1), 159-177 (2012).

[15]. R. Gürkan, and O. Gürkan, "Catalytickinetic spectrophotometric determination of vanadium $(\mathrm{V})$ based on the Celestine blue-bromate-vanadium (V)-citric acid reaction," Rare Metals, 30(4), 348-358 (2011).

[16]. M.L. Lunar, S. Rubio, D. Pérez-Bendito, M.L. Carreto, and C.W. McLeod, "Hexadecylpyridinium chloride micelles for the simultaneous kinetic determination of cysteine and cystine by their induction of the iodine-azide reaction," Analytica chimica acta, 337(3), 341-349 (1997).

[17]. J.S. Esteve-Romero, E.F. Simó-Alfonso, M.C. Garcia-Alvarez-Coque, and G. Ramis-Ramos, "Micellar enhanced spectrophotometric determination of organic species," TrAC Trends in Analytical Chemistry, 14(1), 29-37 (1995).

[18]. E.K. Paleologos, D.L. Giokas, and M.I. Karayannis, "Micelle-mediated separation and cloud-point extraction," TrAC Trends in Analytical Chemistry, 24(5), 426-436 (2005).

[19]. Kazemzadeh, and A.A. Ensafi, "Simultaneous determination of nitrite and nitrate in various samples using flow-injection spectrophotometric detection,' Microchem J, 69, 159-166 (2001)

[20]. S. Prasad, and T. Halafihi, "Standardization of kinetic determination of nitrite based on its catalytic effect on an indicator reaction," Asian J Chem, 14, 16831692 (2002).

[21]. X.F. Yue, Z.Q. Zhang, and H.T. Yan, "Flow injection catalytic spectrophotometric simultaneous determination of nitrite and nitrate," Talanta, 62, 97-101 (2004)

[22]. S.L. Shen, X.N. Chen, and Y.S. Jin, "Catalytic spectrophotometric determination of trace nitrite with methylene blue-hydrogen peroxide system,' Chin J Anal Chem, 30, 14051414 (2002).

[23]. L.S. Bai, and Z.H. Chi, "Kinetic spectrophotometric determination of nitrite by the catalytic oxidation of bromocresol purple with potassium bromate,' Chin J Anal Chem, 29, 926929 (2001).

[24]. A.A. Ensafi, B. Rezaei, and S. Nouroozi, "Simultaneous spectrophotometric determination of nitrite and nitrate by flow injection analysis," Anal Sci, 20, 1749-1753 (2004).

[25]. H.R. Pouretedal, and B. Nazari, "Kinetic spectrophotometric determination of trace amounts of nitrite by catalytic reaction between methylthymol blue and bromate," J Chin Chem Soc, 51, 1353-1356 (2004)

[26]. M. Barzegar, M.F. Mousavi, and A. Nemati, "Kinetic spectrophotometric determination of trace amounts of nitrite by its reaction with molybdosilicic acid blue,'’ Microchemical Journal, 65, 159163 (2000).

[27]. Y. Dong, and C.L. Lu, Spectrophotometric determination of nitrite ion with acridine red based on the nitrosation reaction," Spectrosc Spectr Anal, 21, 710-712 (2001).

[28]. S. Sobhanardakani, A. Farmany, S. Abbasi, J. Cheraghi, and R. Hushmandfar, "A new catalyticspectrophotometric method for 
quantification of trace amounts of nitrite in fruit juice samples," Environmental monitoring and assessment, 185(3), 2595-2601 (2013).

[29]. T. Tomiyasu, Y. Konagayoshi, K. Anazawa, and H. Sakamoto, "A kinetic method for the determination of nitrite by its catalytic effect on the oxidation of chlorpromazine with nitric acid," Analytical sciences, 17, 1437-1440 (2001).

[30]. B. Liang, M. Iwatsuki, and T. Fukasawa, "Catalytic spectrophotometric determination of nitrite using the chlorpromazine-hydrogen peroxide redox reaction in acetic acid medium," Analyst, 119, 2113-2117 (1994).
[31]. E.H. Cordes, "Reaction Kinetics in Micelles," Plenum Press, New York., (1973).

[32]. J.H. Fendler, and E.J. Fendler, "Catalysis in Micellar and Micromolecular Systems Plenum Press," New York, (1975).

[33]. M.L. Lunar, S. Rubio, and D. PerezBendito, "Combination of micellar and chemical catalysis as a means of enhancing the sensitivity of catalytic kinetic determinations," Analytica Chimica Acta, 237, 207-214 (1990). 